\title{
雭罳
}

\section{どうしたら日本人の独創 力を強化できるか？}

川上 正光*

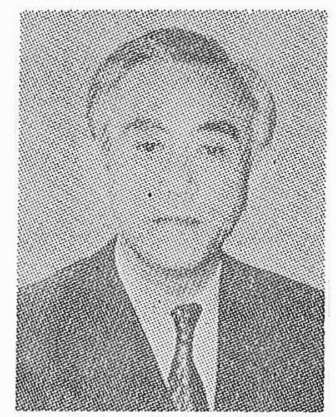

およそ一家が興り，一国が興るのは，その活力と独 創力によることは古今東西の歴史が示している．とこ ろで, 現在日本の繁栄は根なし草の花が咲いたような もので，い枯れるかわからない，今のら号に自分の 力で大地にしっかり根を着けなければならない。しっ かり根を着けるということは独創力を強化することに ほかならない，これは大変困難なことであるが，これ こそ国家百年の大計の根本であると思う。“点滴膂も 穿つ”のたと炏を得ていささか愚見を述べてみた W.

I 国の指導者が真に独創力の必要性を認めること

このためにはいかにわが国の独創力が貧弱であるか を知るべきである。これを例示すると次のと扣りであ る.

（i）世界の研究成果の最高水準を示す Nobel 賞 がさっぱり獲れない。これに関する思い出を述べてお $こ 5$.

昭和 37 年, 筆者は在外研究員としてアメリカに行 き，いくつかの大学を訪問した。 まず, Stanford 大 学に行さ工学部長に面会すると, 彼は開口一番“わが 大学には Nobel 賞受賞者が 6 人いる”というのであ る, 続いて California 大学 (Berkeley Campus) む 同様に 13 人, Columbia 大学でも（出入りを含めて） 18 人と型で押したように Nobel 賞受賞者の話から始 まるのである。このよらにアメリカの大学の目標の高 いことは，わが国の大学と比べて正に雲泥の盖がある ことに驚いたのであった。

（ii）技術貿易も振るわない,アメリカは約 10:1, イギリスとフランスは約 1:1であるのに効して日本と ドイツは約 0.38:1 という低值である. 資源の之しい わが国こそこの soft wear の生産に力を入れるべき である・

（iii） OECD は昭和 51 年にわが国を調㚗し，“日本
の社会科学は知識借用型で, 抽象的概念操作を経験的 事例研究よりも重視し, 創造的な貢献に乏しい”とし ている、この結諭は単に社会科学だけでなく，わが国 学術の全分野に言い党ることではなかららか.

（iv）その他，わが国の内政，外交などについて も，独創性は極めて乏しいと考学るのは筆者たけであ ららか。

\section{II 独創力養成には教育は全く有客であること}

い昰述べたようにわが国の独創力が貧弱である原因 は多々あ万らが，ただ一つはっきりしていることは “幼稚園から大学院まで Teaching (教育) ばかりで, ほとえど Education (啓発教育 $\rightarrow$ 啓育) がなされてい ない”ことである．換言すれば，わが国の学校では始 めから終りまで “物知り人間”を作ることに専念し， 新規なことを考兄出す “独創人間”の養成に努力を 払っていないのである。こうなった最大の原因は Education（才能を引き出すこと）を教育と䛊訳したこ とにあると信ずる.つまり諸外国の学校では Education を行なっているのにわが国では Teaching ばか りしか行なわず, 物知りを優等生としているのが根本 的に間違っているのである. 早く“考え出す人間”を 作るよう切替光るべきである.

III 外発研究体制から内発研究体制に切換えること わが国の研究の大部分は外国に誘発されて行なって おり, 外発の傾向が著しい，日本で何が必要か，国内 の必要に応ずる内発研究をもっと重視すべきである ら。われわれは，早く外国人の頭で考觉ることをやめ て, 自分の頭で考光らではないか.

な拉，研究の実績を岕げるためには，研究費の与え 方をきびしく実績主義によることとしたり，その他予 算制度の改革や寄付研究費の免税措置など諸外国の長 所を取り入れるべきことが残されていると思う。

* Masamitsu Kawakami 長岡技術科学大学 (949-54 長岡市上富岡町字長䀱 1603) 学長.工博

〈略歴〉 昭和 10 東京工業大学電気工学科卒業. 同年東芝(株)入社, 23 年東京工大助教授, 救授を経て, 47 年退官, 同年 横浜国大教授, 48 年東京工大学長, 52 年任期満了. 同年上り現職. 